\title{
Irrigation Water Salinity Influences at Various Growth Stages of Capsicum annuum
}

Gurjinder S Baath, Manoj K. Shukla*, Paul W. Bosland, Robert L. Steiner, and Stephanie J.

Walker

Gurjinder S Baath, Graduate Student, Department of Plant and Environmental Sciences, New Mexico State University, MSC 3Q, P.O. Box 30003, Las Cruces, NM 88003. Tel: 575-646-2324;

Fax: 575-646-6041; e-mail: gsbaath@nmsu.edu

*Manoj K. Shukla, Professor, New Mexico State University, Department of Plant and

Environmental Sciences, MSC 3Q, P.O. Box 30003, Las Cruces, NM 88003-8003. Tel: 575-646-

2324; Fax: 575-646-6041; e-mail: shuklamk@nmsu.edu

Paul W. Bosland, Regents Professor, New Mexico State University, Department of Plant and

Environmental Sciences, MSC 3Q, P.O. Box 30003, Las Cruces, NM 88003-8003. Tel: 575-646-

5171; Fax: 575-646-6041; e-mail: pbosland@nmsu.edu

Robert L. Steiner, Professor, Economics and International Business Department, New Mexico

State University, MSC 3CQ, P.O. Box 30001, Las Cruces, NM 88003-8001. Tel: 575-646-4164;

Fax: 575-646-1915; e-mail: rsteiner@nmsu.edu

Stephanie J. Walker, Assistant Professor, New Mexico State University, Department of

Extension Plant Sciences, MSC 3AE, P.O. Box 30003, Las Cruces, NM 88003-8003. Tel: 575-

646-4398; Fax: 575-646-6041; e-mail: swalker@nmsu.edu

*Corresponding Author: Manoj K Shukla, Tel: 575-646-2324; Fax: 575-646-6041;

e-mail: shuklamk@nmsu.edu 


\begin{abstract}
:
Availability of fresh surface water for irrigation is declining in southern New Mexico, and saline groundwater is increasingly used for irrigation. This study evaluates the effects of irrigation using saline water on the chile pepper plants. The chile pepper (Capsicum annuum L.) cultivars selected include, AZ 1904, NuMex Joe E. Parker, NuMex Sandia Select, LB 25, and 3441. Salt tolerance of these five cultivars was studied at various growth stages including germination, emergence, vegetative growth, flowering and fruiting stages in a greenhouse set up. The five saline treatments included for germination were tap water of EC 0.6 (control), well water of EC 3 and 6, and RO concentrate of EC 8 and $10 \mathrm{dS} / \mathrm{m}$. During plant emergence and growth, natural water ECs for irrigation were 0.6 (control), 3, 5 and $8 \mathrm{dS} / \mathrm{m}$. Increasing irrigation water salinity increased mean germination time but did not affect the final germination percentage. Increasing irrigation water salinity increased mean emergence time but the final percentage emergence was affected significantly only after $\mathrm{EC} \geq 3 \mathrm{dS} / \mathrm{m}$. Plant growth was significantly affected after several weeks of continuous exposure to saline water application ( $\mathrm{EC} \geq 3 \mathrm{dS} / \mathrm{m})$. Increasing salinity decreased days to flowering, photosynthesis, stomatal conductance, relative fresh shoot and fruit weights, and water use efficiency. Results show that the selected chile pepper cultivars can be irrigated up to an irrigation water salinity level of $\leq 3 \mathrm{ds} / \mathrm{m}$. Among all the cultivars, 3441 was found to be the most tolerant to salinity. Environmentally sound reuse of RO concentrate will encourage desalination in water scarce areas and greenhouse chile cultivation. Key-words: chile peppers, flowering, concentrate, salt tolerance, yield, greenhouse
\end{abstract}




\subsection{Introduction:}

Salinity and drought are two of the major abiotic stresses for crop production in many parts of the world including the southwestern United States. These regions are predominantly arid to semiarid and are affected by salinity due to low rainfall, high evapotranspiration and saline groundwater (Niu et al., 2010). With the persistent drought in these regions, the surface water availability for irrigation has declined and groundwater is increasingly used by farmers for irrigation. About $75 \%$ of the available groundwater is saline, with an electrical conductivity $>3$ dS/m (Lansford et al., 1990; WRRI, 1997). Continuous application of saline water can lead to the buildup of salts near the soil surface. Consequently, osmotic potential and nutritional imbalance induce stress in plants and consequently adversely impact growth and yield (Asiraf, 1994; Singh et al., 2014); however, effects of salinity could be a function of the growth stages, species and variety of the plant (Botia et al., 1998).

The responses of crops to salinity often change from one development stage of growth to the next. Most crops show tolerance to salinity during germination with a delay in days to germination (Mass and Poss, 1989a). Unlike germination however, most crops are susceptible during emergence and vegetative development as seedlings are subjected to water stress, varying salinities due to capillary rise and evaporation near the soil surface (Katerji et al., 1994; Pasternak et al., 1979). Plants become progressively more tolerant to salinity with maturity, especially at later stages of development (Lauchli and Epstein, 1990; Foolad, 2007). However, the growth responses to salinity can differ within species. Like sugarbeet (Beta vulgaris L.), a crop known to be salt tolerant during later growth stages is fairly sensitive at germination stage (Jamil and Rha, 2004); and turnip (Brassica campestris L.) has salt tolerance at germination, but is more susceptible to salts at seedling growth (Francois, 1984). In addition, salinity induces 
early flowering in onion (Allium cepa L.), but it delays flowering of tomato (Lycopersicon esculentum L.) (Shannon and Grieve, 1998). Thus, there is variability of growth responses to salt stress within species and quantitative information available on salt tolerance at different growth stages for many of the species is meager.

Chile pepper is an important cash crop of Southwestern United States, with nearly 8,000 to 10,000 acres harvested annually in New Mexico with a processed value estimated to be $\$ 500$ million (Bosland and Walker, 2014). It has been classified as moderately sensitive to salinity with a threshold level of $1.5 \mathrm{dS} / \mathrm{m}$, above which yield begins to decline (Maas and Hoffman, 1977). Some studies have reported that the seedling stage of chile pepper is more sensitive to salinity than germination (Chartzoulakis and Klapaki, 2000; Niu et al., 2010). Introduction of salt tolerant genotypes could be an effective way to eliminate salinity effects for all crops including chile pepper. Limited studies have reported that some chile pepper genotypes are more salt tolerant than others (Atkas, 2006; Chartzoulakis and Klapaki, 2000; Niu et al., 2010). Thus, it is necessary to examine the stress response of different varieties of chile pepper at various growth stages for sustaining crop production.

Salt components in the irrigation water can have a large variability across the globe. However, $\mathrm{Na}^{+}, \mathrm{Ca}^{2+}$ and $\mathrm{Mg}^{2+}$ are dominant cations, and $\mathrm{Cl}^{-}, \mathrm{SO}_{4}{ }^{2-}$ and $\mathrm{HCO}_{3}{ }^{-}$are the dominant anions in most of the groundwater (Grattan and Grieve, 1998). To our knowledge, most of the saline studies conducted so far on peppers used $\mathrm{NaCl}$ either as sole or as dominant salinizing agent (Aktas et al., 2006; Chartzoulakis and Klapaki, 2000; Demir and Mavi, 2008; Niu et al., 2010; Yildirim and Güvenç, 2006). Therefore, research on the use of natural brackish groundwater for irrigation is needed for sustaining chile pepper production in arid areas including the southwestern USA. Objectives of the study were to assess 1) the effect of saline 
groundwater irrigation at various growth stages of chile peppers; and 2) the relative salt tolerance of five chile peppers cultivars. This study was conducted in a greenhouse environment because there is a potential of greenhouse chile pepper production in New Mexico and New Mexico Department of Agriculture does not allow land application of water with EC> $4 \mathrm{dS} / \mathrm{m}$.

\subsection{Materials and Methods}

This study was carried out in a greenhouse located at the Fabian Garcia Science Center of New Mexico State University (NMSU), Las Cruces, New Mexico (32.2805 $\mathrm{N}$ latitude and $106.770^{\circ} \mathrm{W}$ longitude at an elevation of $1186 \mathrm{~m}$ above sea level). The average air temperature in the greenhouse recorded during the entire experiment was $32.44 \pm 0.16{ }^{0} \mathrm{C}$ during day and $24.22 \pm 0.12{ }^{0} \mathrm{C}$ during night. Five chile pepper cultivars were selected for this study. NuMex Joe E. Parker and NuMex Sandia Select are NMSU cultivars. Seeds of the remaining three cultivars were obtained from various seed suppliers (AZ 1904 from Curry Chile and Seed, Pearce, AZ; LB25 from Biad Chile, Leasburg, NM; and 3441 from Olam, Las Cruces, NM). Natural saline well water and concentrate coming out of the reverse osmosis (RO) system were used for irrigation. Both well water and RO concentrate were provided by the Brackish Groundwater National Desalination Research Facility (BGRNDRF), Alamogordo, NM.

\subsection{Germination experiment}

A replicated germination experiment was conducted in petri dishes $(100 \mathrm{~mm}$ diameter, 16 mm height). The salinity treatments consisted of five levels including tap water of EC 0.6 (control), well water of EC 3 and 6 and RO concentrate of EC 8 and $10 \mathrm{dS} / \mathrm{m}$. In each petri dish four filter papers were placed and moistened with different levels of saline water, and excess water was drained. For each chile pepper cultivar, 25 seeds were placed on the moistened filter paper. Petri dishes were tightly sealed using parafilm to avoid evaporation. The experiment was 
conducted on a greenhouse bench and petri dishes were protected from direct sunlight by black shade cloth placed above the dishes so that air movement was not restricted. Based on the reduction in weight of petri dish, about $1 \mathrm{ml}$ of tap water was added to each petri dish once every week to replenish the lost moisture. Seeds were considered germinated and removed once the length of the radicle surpassed the length of the seed. Ungerminated seeds remained in the dish until the conclusion of the study and their viability was determined using the imbibed crush test. The number of seeds germinated was counted daily and final germination was determined after 28 days. The experiment was a completely randomized design with four replications of each combination of treatments.

\subsection{Emergence Experiments}

Replicated emergence experiments were conducted in the soil collected from the Fabian Garcia Science Center of NMSU (Table 1). Irrigation waters including, brackish well waters and RO concentrate, were collected once a month from BGNDRF and chemical analysis was performed (Table 2). Additionally greenhouse environmental parameters varied, therefore, two experiments for emergence were conducted simultaneously side by side in the greenhouse.

Soil was air dried, gently crushed, and sieved through a $4 \mathrm{~mm}$ sieve. Soil, sand, and organic peat were mixed thoroughly in the ratio 8:1:1 on a volume basis. Soil mix was sterilized in an oven at a temperature of $180^{\circ} \mathrm{F}$ for 30 minutes. Cylindrical pots of $6.5 \mathrm{~cm}$ diameter and 25 $\mathrm{cm}$ length were used in the experiment. The perforated bottom of each pot was covered with cheese cloth to prevent soil loss and gravel were placed on the bottom to allow free drainage. Packing of the soil was done in $5 \mathrm{~cm}$ depth increments to obtain a homogenous profile. Soil was washed three times with tap water to leach any pre-existing salts. Four natural water treatments selected for irrigation were: tap water of EC 0.6, well water of EC 3 and 5 and RO concentrate of 
EC $8 \mathrm{dS} / \mathrm{m}$. Before sowing seeds, soil was irrigated twice with each of the water treatment to raise the soil salinity to the water treatment level. Sowing was done by placing four seeds of each chile pepper within a soil depth of 1-2 cm. Emergence was recorded at a two day intervals and final emergence was determined 35 days after sowing. Irrigation water treatments were continuously applied at an interval of 3 to 4 days, based on the change in weights of reference pots.

\subsection{Growth Stages}

The most vigorous seedling from the emergence experiment was saved 35 days after sowing and only one seedling was retained in each pot. Irrigation treatments used in the emergence experiment were continued. In one liter of each of the irrigation water treatments $2 \mathrm{~g}$ of Miracle-gro fertilizer was added and applied at the flowering stage and later at the fruiting stage. Height of each plant from the soil surface to the top of the main stem was measured once a month. Days to flower initiation from sowing date were recorded for each plant. At fruiting, physiological measurements including photosynthesis $(\mathrm{Pn})$ and stomatal conductance $\left(\mathrm{g}_{\mathrm{s}}\right)$ were recorded during midday using a portable photosynthesis system (Model LI-COR 6400, Lincoln, NE, USA). From each plant the two topmost, fully expanded, illuminated and healthy leaves were selected for measurement. Pods were harvested when they reached horticultural green mature stage and fresh pod weights were measured. Plants were hand harvested at the end of the growing season and fresh weights of shoots were recorded. Cultivars selected in this study have natural variations in height and yield under normal conditions. Thus, relative plant height was obtained as the ratio of actual height and the maximum height by variety, relative fresh shoot weight as the ratio of actual and maximum weight by variety, and relative fruit yield as the ratio of actual yield and the maximum yield by variety. Irrigation water use efficiency (IWUE) was 
calculated as the ratio of total yield of each plant and the total irrigation water applied to that pot (Sharma et al., 2015).

\subsection{Statistical Analysis}

The petri dishes for germination experiment and cylindrical pots for emergence experiments were arranged in a completely randomized design with four replicates by generating random numbers using data analysis in Microsoft Excel (2013). The data for whole experiment were analyzed using two-way analysis of variance (ANOVA) and proc GLM (SAS) for identifying significant differences at alpha 5\% (SAS institute, 2013). The means were separated using Least Significance Difference (LSD) at 5\% significance level $(p \leq 0.05)$. Prior to ANOVA, the data were confirmed for normality distribution based on Shapiro-Wilk statistic (Shapiro and Wilk, 1965) using the univariate procedure for SAS. The residuals for all except one of the data were normally distributed with $\mathrm{W}$-statistic ranging from 0.970 to $0.993(p>0.05)$. Stomatal conductance in experiment 2 was the only slightly non normal data with W-statistic of 0.969 $(p=0.048)$. The reason could be due to the high power of Shapiro-Wilk test for large sample sizes (Razali and Wah, 2011). The non normal data was log transformed but results for ANOVA and LSD comparison remained unchanged. Since ANOVA is reported to be not very sensitive to moderate deviation from normality (Glass et al., 1972; Norman, 2010; Schmider et al., 2010), the actual non-transformed data were used in this study.

\subsection{Results}

\subsection{Irrigation Water Salinity and Germination}

The germination percentage of five cultivars differed significantly $(p \leq 0.05)$ when averaged across the water salinity treatments (Table 3). The maximum germination was at $93 \%$ for AZ 1904, while the minimum germination of $80.6 \%$ was obtained for LB 25. However, 
average germination percentage of all five cultivars did not show any statistically significant difference with increasing irrigation water salinity. The mean germination time significantly increased above $3 \mathrm{dS} / \mathrm{m}$ treatment. Among the five cultivars, LB 25 took the longest time to germinate, whereas 3441 and AZ 1904 seeds took the least. There was no significant interaction between cultivars and water salinity levels for percent germination and germination time.

\subsection{Irrigation Water Salinity and Emergence}

Significant differences were observed among the cultivars and water salinity levels for percent emergence and mean emergence time, while there was no significant interaction (Table 4). Among cultivars, 3441 had the highest percent emergence and the least mean time for emergence, which were statistically similar to AZ 1904. LB 25 had the least percent emergence and the longest mean emergence time, which were statistically similar to NuMex Sandia Select and NuMex Joe E. Parker. Among water salinity levels, the average percentage emergence of five cultivars was statistically similar in 0.6 (control) and $3 \mathrm{dS} / \mathrm{m}$, while it was significantly less in 5 and $8 \mathrm{dS} / \mathrm{m}$ treatments. Mean emergence time increased significantly with increasing irrigation water salinity $(\mathrm{P}<0.05)$.

\subsection{Irrigation Water Salinity and Plant Height}

Uniform seedlings were retained after the emergence, and there was no significant difference in the relative plant heights of cultivars 10 days after emergence except NuMex Sandia Select in experiment 1 (Fig. 1A) and AZ 1904 in experiment 2 (Fig. 1C). In experiment 1, 100 days after emergence, no significant differences in relative plant height were observed for 3441, NuMex Joe E. Parker and NuMex Sandia Select followed by LB 25 and AZ 1904. In experiment 2, no significant differences in relative plant height were observed for 3441 and NuMex Joe E. Parker, but they were significantly higher than AZ 1904, NuMex Sandia Select 
and LB 25. Significant salinity effect on the relative height of plants irrigated with 5 and $8 \mathrm{dS} / \mathrm{m}$ saline levels appeared 40 days after emergence (Fig. 1B and Fig. 1D). However, by 70 days after emergence, relative plant heights significantly decreased with increasing irrigation water salinity from 0.6 to $8 \mathrm{dS} / \mathrm{m}(\mathrm{P}<0.05)$.

\subsection{Irrigation Water Salinity and Flowering}

Days to flowering decreased significantly with increasing water salinity $((\mathrm{P}<0.05$; Table 5). Plants irrigated with 0.6 (control) and $3 \mathrm{dS} / \mathrm{m}$ saline water treatments needed more days to flower than plants irrigated with 5 and $8 \mathrm{dS} / \mathrm{m}$ waters. Among the cultivars, LB 25 and 3441 plants flowered more rapidly than NuMex Sandia Select, NuMex Joe E. Parker and AZ 1904, the last three cultivars were in the same statistical group.

\subsection{Irrigation Water Salinity and Plant Physiology}

Photosynthesis rate differed slightly among cultivars with irrigation water salinity levels (Table 6). Pn for 3441 was least affected across salinity levels followed by LB 25, while NuMex Joe E. Parker was most affected and was similar to AZ 1904 and NuMex Sandia Select. The average Pn of five cultivars generally decreased with increasing water salinity and the lowest Pn was observed at $8 \mathrm{dS} / \mathrm{m}$ level. The highest Pn was recorded in $0.6 \mathrm{dS} / \mathrm{m}$ (control) treatment in both of the experiments. Stomatal conductance variations among the cultivars were also small. NuMex Joe E. Parker and NuMex Sandia Select showed minimum conductance. However, like Pn, average gs of five cultivars also decreased significantly with the increasing irrigation water salinity $(\mathrm{P}<0.05)$.

\subsection{Irrigation Water Salinity and Plant Biomass}

No significant differences were noted for relative biomass yields among cultivars (Table 7). Although, the average relative biomass yield of the five cultivars decreased significantly with 
increasing salinity levels it was not statistically different at 5 and $8 \mathrm{dS} / \mathrm{m}$ levels. 3441 produced maximum relative fruit yield in both experiments but was only statistically different from NuMex Sandia Select in experiment 1. The average relative fruit yield of the five cultivars was found to decrease with increasing water salinity. Maximum relative fruit yield was observed in 0.6 (control), while the minimum was in $8 \mathrm{dS} / \mathrm{m}$ although no statistically significant differences were noted between 5 and $8 \mathrm{dS} / \mathrm{m}$ treatments in experiment 2 .

Irrigation water use efficiency (IWUE) showed a significant decrease with increasing irrigation water salinity (Fig. 2B and Fig. 2D). The decrease in IWUE was about 13\% in $3 \mathrm{dS} / \mathrm{m}$ from control; while in the 5 and $8 \mathrm{dS} / \mathrm{m}$ treatments, the decrease was $48 \%$ and $51 \%$, respectively. However, only a slight difference in IWUE was observed among the cultivars (Fig. 2A and Fig. 2C). LB 25 was found to be most water efficient in both the experiments.

\subsection{Discussion}

No significant differences in germination percentage were noted and mean germination time increased by more than one day between control and concentrate $(10 \mathrm{dS} / \mathrm{m})$ treatments. Results of germination study were similar to those reported by Chartzoulakis and Klapaki (2000) and Yildirim and Güvenç (2006). Flores et al., (2015) also observed similar results for six halophyte species using similar saline water treatments. Emergence of chile peppers was found to be similar up to $3 \mathrm{dS} / \mathrm{m}$, suggesting that seedlings can be grown by using slightly saline water. However, emergence decreased with further increase in irrigation water salinity. Similar results were reported in other salinity studies conducted in pepper (Chartzoulakis and Klapaki, 2000; Miyamoto et al., 1985; Yildirim and Güvenç, 2006). The emergence of chile peppers appeared to be affected due to post germination mortality of hypocotyl linked with salts accumulated at the soil surface, also reported in alfalfa (Medicago 
sativa L.) (Assadian and Miyamoto, 1987) and chickpea (Cicer arietinum L.) (Esechie et al., 2002). In our study, emergence of chile pepper was delayed with increasing salinity. To our knowledge, it has not been reported in chile peppers so far, while Al-Harbi et al. (2008) and Kaveh et al. (2011) also observed delay in emergence with increasing salinity in tomato (Lycopersicon esculentum $L$.). The delay in emergence was assumed to be associated with delayed germination and retardation in the radical growth under the influence of salinity.

During the experimental period, plant heights were recorded at monthly interval. It was demonstrated that relative plant heights were similar in 0.6 (control) and $3 \mathrm{dS} / \mathrm{m} 40$ days after emergence, indicating that chile peppers can tolerate irrigation with low saline water for a short periods of time. However, after 70 days of continuous exposure, gradual stunting in growth was observed with increasing salinity. Chartzoulakis and Klapaki (2000) and Yildirim and Güvenç (2006) also found decreases in height of peppers with increasing salinity. The inhibition of plant growth begins by cellular response to decreased water availability caused by osmotic stress of external salts and furthered later on by toxic effects of excessive salt accumulation within the plant (Munns et al., 1995). Among cultivars, growth was similar in the beginning and differences appeared after several weeks of continued exposure to salinity. Neumann (1997) also suggested that appearance of varietal differences in plant growth is only expected after a long-term exposure to salinity.

With increasing salinity levels, phonological traits like days to flowering decreased. To the best of our knowledge, no such results have been reported for chile peppers. While, Mass and Grieve (1990) and Grieve et al. (1994) observed a shorter time to flowering in wheat (Triticum aestivum $L$.) and concluded that salinity fastens shoot apex development and initiates 
reproductive structures more rapidly. Among the cultivars, there was also a slight difference in terms of flower initiation due to genetic variation.

Pn and $g_{s}$ of chile pepper cultivars significantly lower with increasing salinity levels. Pn was about $11 \%, 23 \%$, and $30 \%$ lower in 3,5 , and $8 \mathrm{dS} / \mathrm{m}$ saline water treatment than control, respectively. However, gs was about $26 \%, 50 \%$, and $63 \%$ lower in 3, 5, and $8 \mathrm{dS} / \mathrm{m}$ than control, respectively. The lower $\mathrm{Pn}$ in saline treatments could be due to restriction of $\mathrm{CO}_{2}$ entry through stomata. This decline in Pn under stress conditions has been attributed to decreased $\mathrm{g}_{\mathrm{s}}$ in some other studies (Delfine et al., 1999; Rasmuson and Anderson, 2002; Singh et al., 2014). While in the cultivars tested here, Pn and $g_{s}$ were not very different, LB 25 and 3441 had higher Pn and $g_{s}$ among the cultivars across saline treatments.

Relative shoot weights and relative fruit yields also showed an inverse relationship with increasing water salinity. Decrease in plant height, photosynthesis, and stomatal conductance with increasing salinity contributed to lower fruit yield and shoot weight. The reduction in fruit yield and shoot weight with salinity was in agreement with other salinity studies conducted on peppers (Chartzoulakis and Klapaki, 2000; Yildirim and Güvenç, 2006; Pascale et al., 2003; Navarro et al., 2002). There were no significant differences among the cultivars for relative shoot weights. At the time of harvesting, some of the cultivars were matured and already starting to shed leaves while others had more leaves, which could be the reason for the similar shoot weights. In this study, decrease in IWUE (irrigation water use efficiency) was only $13 \%$ when chile pepper plants were irrigated with $3 \mathrm{dS} / \mathrm{m}$ of saline water, which can be considered acceptable if saline water is the only water available for irrigation. No interactions between cultivars and water salinity levels for any of the discussed parameters suggested that all cultivars responded to salinity in the same manner. This study showed that continuous application of 
saline water and RO concentrate will result in yield decreases. Therefore, future research should focus on the early flowering due to the application of brackish groundwater and RO concentrate, and a new irrigation scheduling protocol using saline waters should be developed to sustain yields while simultaneously reusing RO concentrate.

\subsection{Conclusion}

This study was conducted to test the emergence, growth, and survival of chile peppers irrigated with natural brackish well water and RO concentrate. Irrigation with increasing water salinity resulted in less and delayed emergence, stunted plant growth, low photosynthesis and stomatal conductance, accompanied by considerable decrease in fresh weights of shoots and fruits. It was also observed that plants grown in saline water treatments 0.6 (control) and $3 \mathrm{dS} / \mathrm{m}$ were not much different in response to salinity. Thus, irrigation with saline water up to $3 \mathrm{dS} / \mathrm{m}$ is

possible, at least for one growing season, for sustaining chile pepper production. However, more experiments should be done to determine how long irrigation with $3 \mathrm{dS} / \mathrm{m}$ could be sustained without significant yield reductions, and appropriate leaching fractions. Among cultivars, 3441 showed more tolerance due to higher fruit yield and less fluctuation in shoot weight and height across different salinity levels as compared to other cultivars. Its salt tolerance was also associated with the ability to maintain high photosynthesis and stomatal conductance. Although, LB 25 and 3441 showed similar results for most of the parameters, LB 25 was the most sensitive cultivar of the five cultivars tested at emergence stage. Overall cultivar 3441 was the most tolerant among five cultivars tested and would be a good candidate cultivar for irrigation with saline water.

\section{Acknowledgement}


Authors thank New Mexico State University Agricultural Experiment Station for the financial support through Graduate Research Award. This work was partially supported by the USDA National Institute of Food and Agriculture, Hatch project 1006850, and Nakayama Chair endowment. Authors also thank Brackish Groundwater National Desalination Research Facility in Alamogordo, NM for providing the groundwater and $\mathrm{RO}$ concentrate.

\section{References:}

Aktas, H., Abak, K., \& Cakmak, I. (2006). Genotypic variation in the response of pepper to salinity. Scientia horticulturae, 110(3), 260-266.

Al-Harbi, A. R., Wahb-Allah, M. A., \& Abu-Muriefah, S. S. (2008). Salinity and nitrogen level affects germination, emergence, and seedling growth of tomato. International journal of vegetable science, 14(4), 380-392.

Ashraf, M. Y., \& Wu, L. (1994). Breeding for salinity tolerance in plants. Critical Reviews in Plant Sciences, 13(1), 17-42.

Assadian, N. W., \& Miyamoto, S. (1987). Salt effects on alfalfa seedling emergence. Agronomy Journal, 79(4), 710-714.

Bosland, P. W., \& Walker, S. (2014). Growing chiles in New Mexico. Cooperative Extension Service, College of Agriculture and Home Economics, New Mexico State University.

Botía, P., Carvajal, M., Cerdá, A., \& Martínez, V. (1998). Response of eight Cucumis melo cultivars to salinity during germination and early vegetative growth. Agronomie, 18(8-9), 503513.

Chartzoulakis, K., \& Klapaki, G. (2000). Response of two greenhouse pepper hybrids to $\mathrm{NaCl}$ salinity during different growth stages. Scientia Horticulturae,86(3), 247-260. 
Delfine, S., Alvino, A., Villani, M. C., \& Loreto, F. (1999). Restrictions to carbon dioxide conductance and photosynthesis in spinach leaves recovering from salt stress. Plant Physiology, 119(3), 1101-1106.

Demir, I., \& Mavi, K. (2008). Effect of salt and osmotic stresses on the germination of pepper seeds of different maturation stages. Brazilian Archives of Biology and Technology, 51(5), 897902.

Esechie, H. A., Al-Saidi, A., \& Al-Khanjari, S. (2002). Effect of sodium chloride salinity on seedling emergence in chickpea. Journal of Agronomy and Crop Science, 188(3), 155-160. Flores, A.M., Schutte, B.J., Shukla, M.K., Picchioni, G.A. and Ulery, A.L. (2015), Seed Science and Technol., 43, 541-547(7).

Glass, G. V., Peckham, P. D., \& Sanders, J. R. (1972). Consequences of failure to meet assumptions underlying the fixed effects analyses of variance and covariance. Review of educational research, 42(3), 237-288.

Grattan, S. R., \& Grieve, C. M. (1998). Salinity-mineral nutrient relations in horticultural crops. Scientia Horticulturae, 78(1), 127-157.

Grieve, C. M., Francois, L. E., \& Maas, E. V. (1994). Salinity affects the timing of phasic development in spring wheat. Crop Science, 34(6), 1544-1549.

Kaveh, H., Nemati, H., Farsi, M., \& Jartoodeh, S. V. (2011). How salinity affect germination and emergence of tomato lines. J Biol Environ Sci, 5(15), 159-163.

Lansford, R., Hernandez, J., Enis, P., Truby, D., and Mapel, C. (1990). Evaluation of available saline water resources in New Mexico for the production of microalgae. Solar Energy Research Institute, Golden, CO. 
Maas, E. V., \& Grieve, C. M. (1990). Spike and leaf development of salt-stressed wheat. Crop Science, 30(6), 1309-1313.

Maas, E. V., \& Hoffman, G. J. (1977). Crop salt tolerancel-current assessment. Journal of the irrigation and drainage division, 103(2), 115-134.

Miyamoto, S., Piela, K., \& Petticrew, J. (1985). Salt effects on germination and seedling emergence of several vegetable crops and guayule. Irrigation science, 6(3), 159-170.

Munns, R., Schachtman, D. P., \& Condon, A. G. (1995). The significance of a two-phase growth response to salinity in wheat and barley. Functional Plant Biology, 22(4), 561-569.

Neumann, P. (1997). Salinity resistance and plant growth revisited. Plant Cell and Environment, 20(9), 1193-1198.

Niu, G., Rodriguez, D. S., Call, E., Bosland, P. W., Ulery, A., \& Acosta, E. (2010). Responses of eight chile peppers to saline water irrigation. Scientia horticulturae, 126(2), 215-222.

Niu, G., Rodriguez, D. S., Cabrera, R., Jifon, J., Leskovar, D., \& Crosby, K. (2010). Salinity and soil type effects on emergence and growth of pepper seedlings. HortScience, 45(8), 1265-1269. Norman, G. (2010). Likert scales, levels of measurement and the "laws" of statistics. Advances in health sciences education, 15(5), 625-632.

Rasmuson, K. E., \& Anderson, J. E. (2002). Salinity affects development, growth, and photosynthesis in cheatgrass. Journal of range management, 80-87.

Razali, N. M., \& Wah, Y. B. (2011). Power comparisons of shapiro-wilk, kolmogorov- smirnov, lilliefors and anderson-darling tests. Journal of Statistical Modeling and Analytics, 2(1), 21-33.

SAS Institute. (2013). SAS Institute version 9.4.

Schmider, E., Ziegler, M., Danay, E., Beyer, L., \& Bühner, M. (2010). Is it really robust?. Methodology. 
Sharma, H., Shukla, M. K., Bosland, P. W., \& Steiner, R. L. (2015). Physiological Responses of Greenhouse-grown Drip-irrigated Chile Pepper under Partial Root Zone Drying. HortScience, 50(8), 1224-1229.

Singh, S., Grover, K., Begna, S., Angadi, S., Shukla, M., Steiner, R., \& Auld, D. (2014). Physiological response of diverse origin spring safflower genotypes to salinity. J. Arid Land Studies, 24, 169-174.

WRRI (Water Resources Research Institute). (1997). Transboundary aquifers of the El Paso/Ciudad Juarez/Las Cruces region. Texas Water Development Board and New Mexico Water Resources Research Institute. U.S. Environmental Protection Agency, Region VI.

Yildirim, E., \& Güvenç, İ. (2006). Salt tolerance of pepper cultivars during germination and seedling growth. Turkish journal of agriculture and forestry,30(5), 347-353. 

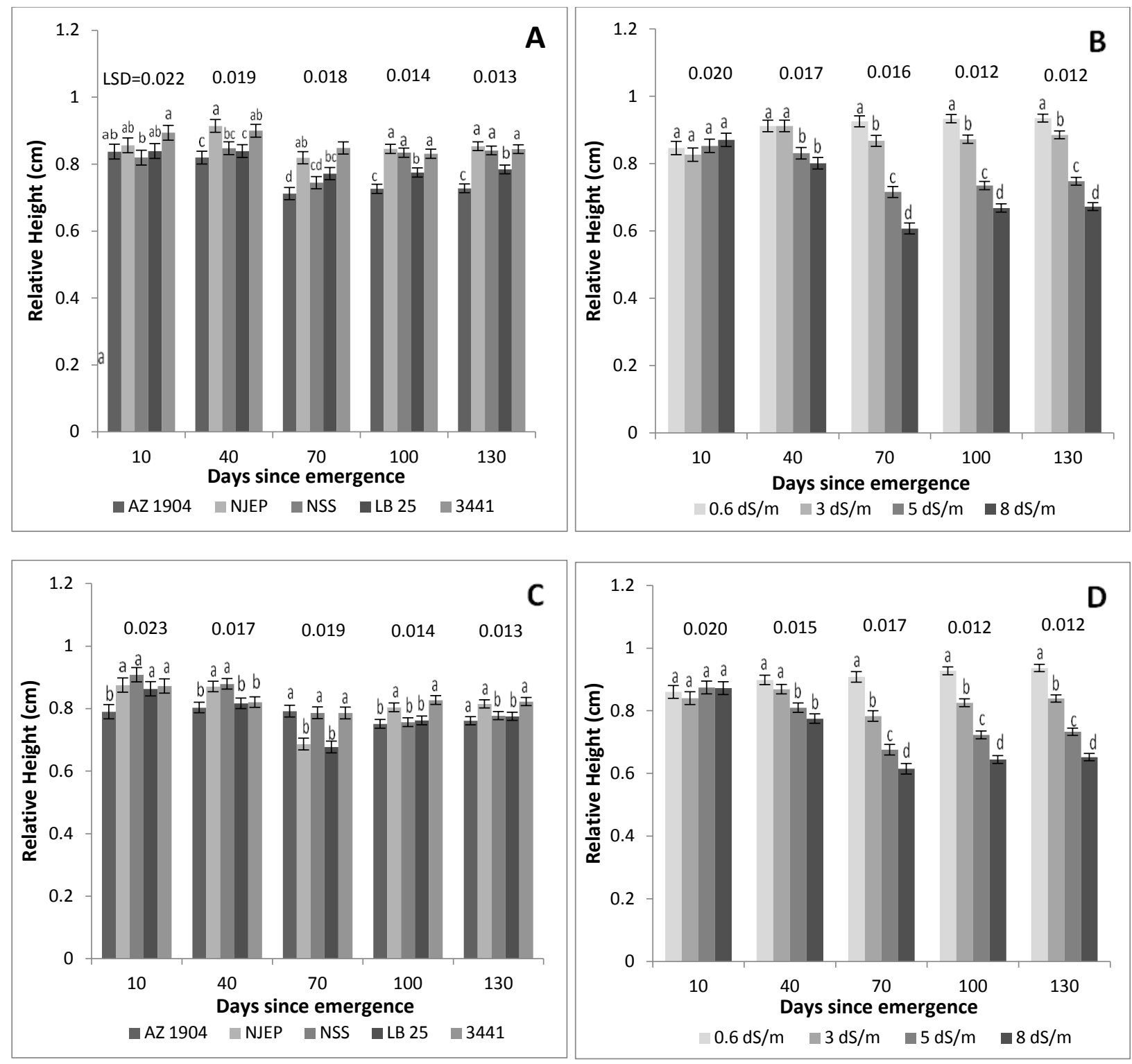

Figure 1: (A) and (C) Relative plant height of five chile pepper cultivars across irrigation water salinity levels in experiment 1 and 2 respectively. (B) and (D) Relative plant height of chile pepper cultivars as affected by four irrigation water salinity levels in experiment 1 and 2 respectively.

Bars with the same letter are not significantly different according to least significance difference test at $p \leq 0.05$. Error bars are standard errors.

NJEP: NuMex Joe E. Parker; NSS: NuMex Sandia Select 


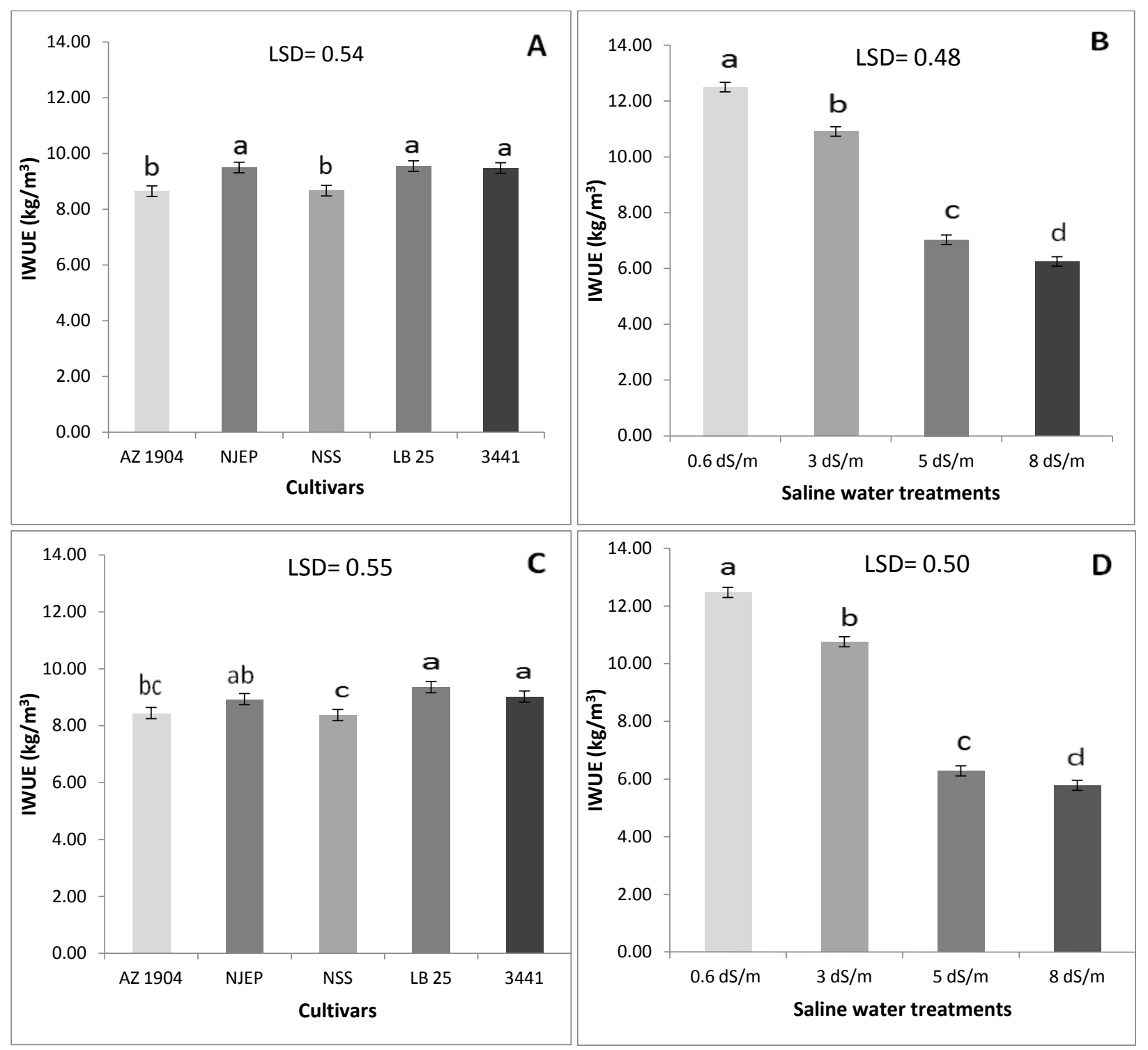

Figure 2: (A) and (C) Effect of saline waters irrigation on IWUE (Irrigation water use efficiency) of five different chile pepper cultivars in experiment 1 and 2 respectively. (B) and (D) IWUE of chile-pepper cultivars as effected by four saline waters irrigation in experiment 1 and 2 respectively.

Bars with the same letter are not significantly different according to least significance difference test at $p \leq 0.05$. Error bars are standard errors.

NJEP: NuMex Joe E. Parker; NSS: NuMex Sandia Select 
Table 1: Mean \pm SE (standard error) for some of the physiochemical properties of soil used for experiments.

\begin{tabular}{|c|c|c|c|c|c|c|c|c|c|}
\hline Sand & Silt & Clay & BD & Catior & (meq/L & & SAR & pH & EC \\
\hline$(\%)$ & $(\%)$ & (\%) & & Mg & $\mathbf{C a}$ & $\mathrm{Na}$ & & & $(\mathrm{dS} / \mathrm{m})$ \\
\hline $\begin{array}{r}78.70 \\
\pm 0.09\end{array}$ & $\begin{array}{r}11.00 \\
\pm 0.12\end{array}$ & $\begin{array}{l}10.30 \\
\pm 0.03\end{array}$ & $\begin{array}{l}1.36 \\
\pm 0.01\end{array}$ & $\begin{array}{l}1.38 \\
\pm 0.22\end{array}$ & $\begin{array}{l}2.75 \\
\pm 0.09\end{array}$ & $\begin{array}{l}4.88 \\
\pm 0.19\end{array}$ & $\begin{array}{l}3.41 \\
\pm 0.01\end{array}$ & $\begin{array}{l}7.80 \pm \\
0.03\end{array}$ & $\begin{array}{l}0.87 \\
\pm 0.02\end{array}$ \\
\hline
\end{tabular}

BD: Bulk Density, SAR: sodium adsorption ratio, EC: electrical conductivity

Table 2: Mean \pm SE (standard error) for chemical properties of four saline waters over the growing season.

\begin{tabular}{llllllll}
\hline $\begin{array}{l}\text { Saline } \\
\text { water } \\
(\mathbf{d S} / \mathbf{m})\end{array}$ & $\mathbf{9 g}$ & $\mathbf{C a}$ & $\mathbf{N a}$ & $\mathbf{K}$ & $\mathbf{C l}$ & \multicolumn{2}{c}{ SOR } \\
\cline { 2 - 7 } & & & & & & \\
\hline 0.6 & $0.73 \pm 0.01$ & $2.16 \pm 0.01$ & $2.61 \pm 0.04$ & $0.17 \pm 0.00$ & $1.70 \pm 0.06$ & $1.68 \pm 0.01$ & $2.17 \pm 0.03$ \\
3 & $8.55 \pm 0.50$ & $12.60 \pm 0.43$ & $9.09 \pm 0.15$ & $0.14 \pm 0.00$ & $12.10 \pm 0.03$ & $19.30 \pm 0.99$ & $2.79 \pm 0.01$ \\
5 & $15.30 \pm 0.32$ & $17.60 \pm 2.08$ & $18.30 \pm 1.76$ & $0.20 \pm 0.03$ & $16.20 \pm 1.91$ & $39.40 \pm 4.01$ & $4.57 \pm 0.60$ \\
8 & $26.40 \pm 0.11$ & $28.60 \pm 3.26$ & $34.90 \pm 2.71$ & $0.39 \pm 0.05$ & $30.70 \pm 5.05$ & $65.50 \pm 8.34$ & $6.70 \pm 0.71$ \\
\hline
\end{tabular}

0.6 is control; SAR: sodium adsorption ratio

Table 3: Effect of water salinity levels on germination (\%) and mean germination time of seeds of five chile pepper cultivars.

\section{Germination (\%)}

Mean Germination Time (days)

\section{Cultivars (C)}

AZ 1904

NuMex Joe E. Parker

3441

NuMex Sandia Select

LB 25

LSD (0.05)
$93.00 \mathrm{a}$

$92.40 \mathrm{a}$

$87.40 \mathrm{~b}$

$82.80 \mathrm{c}$

$80.60 \mathrm{c}$

4.31
$7.53 \mathrm{c}$

$8.58 \mathrm{~b}$

$7.74 \mathrm{c}$

8.42 b

$9.40 \mathrm{a}$

0.67 


$\begin{array}{lll}\text { Salinity (S; dS/m) } & 87.00 \mathrm{a} & 7.57 \mathrm{c} \\ 0.6 \text { (control) } & & \\ 3 & 87.60 \mathrm{a} & 7.62 \mathrm{c} \\ 6 & 88.00 \mathrm{a} & 8.36 \mathrm{~b} \\ 8 & 87.60 \mathrm{a} & 8.92 \mathrm{ab} \\ 10 & 86.00 \mathrm{a} & 9.19 \mathrm{a} \\ \text { LSD }(0.05) & 4.31 & 0.67 \\ \text { C x S } & \text { NS } & \text { NS }\end{array}$

$\dagger$ Values within each column followed by same letter(s) are not significantly different according to least significance difference test $(p \leq 0.05)$.

$\mathrm{NS}=$ Non-significant at $p \leq 0.05$.

Table 4: Effect of water salinity levels on emergence (\%) and emergence time of five chile pepper cultivars.

\begin{tabular}{|c|c|c|c|c|}
\hline & \multicolumn{2}{|c|}{ Experiment 1} & \multicolumn{2}{|c|}{ Experiment 2} \\
\hline & $\begin{array}{l}\text { Emergence } \\
(\%)\end{array}$ & $\begin{array}{l}\text { Mean } \\
\text { Emergence } \\
\text { Time (days) }\end{array}$ & Emergence (\%) & $\begin{array}{l}\text { Mean } \\
\text { Emergence } \\
\text { Time (days) }\end{array}$ \\
\hline \multicolumn{5}{|l|}{ Cultivars (C) } \\
\hline AZ 1904 & $68.75 \mathrm{ab}$ & $12.51 \mathrm{~b}$ & $70.31 \mathrm{ab}$ & $12.38 \mathrm{~b}$ \\
\hline NuMex Joe E. Parker & $56.25 \mathrm{bc}$ & $13.56 \mathrm{a}$ & $57.81 \mathrm{bc}$ & $13.13 \mathrm{a}$ \\
\hline 3441 & $73.44 \mathrm{a}$ & $12.37 \mathrm{~b}$ & $71.87 \mathrm{a}$ & $12.27 \mathrm{~b}$ \\
\hline NuMex Sandia Select & $60.94 a b c$ & $13.33 \mathrm{a}$ & $59.37 \mathrm{abc}$ & $13.48 \mathrm{a}$ \\
\hline LB 25 & $51.56 \mathrm{c}$ & $13.72 \mathrm{a}$ & $53.12 \mathrm{c}$ & $13.51 \mathrm{a}$ \\
\hline $\operatorname{LSD}(0.05)$ & 12.55 & 0.77 & 12.61 & 0.58 \\
\hline \multicolumn{5}{|l|}{ Salinity (S, dS/m) } \\
\hline 0.6 (control) & $77.50 \mathrm{a}$ & $11.19 \mathrm{~d}$ & $75.00 \mathrm{a}$ & $11.02 \mathrm{~d}$ \\
\hline 3 & $71.25 \mathrm{a}$ & $12.15 \mathrm{c}$ & $73.75 \mathrm{a}$ & $11.95 \mathrm{c}$ \\
\hline
\end{tabular}




$\begin{array}{lllll}5 & 55.00 \mathrm{~b} & 14.10 \mathrm{~b} & 53.75 \mathrm{~b} & 13.99 \mathrm{~b} \\ 8 & 45.00 \mathrm{~b} & 14.95 \mathrm{a} & 47.50 \mathrm{~b} & 14.88 \mathrm{a} \\ \operatorname{LSD}(0.05) & 11.23 & 0.69 & 11.27 & 0.52 \\ \text { Cx S } & \text { NS } & \text { NS } & \text { NS } & \text { NS }\end{array}$

$\dagger$ Values within each column followed by same letter(s) are not significantly different according to least significance difference test $(p \leq 0.05)$.

$\mathrm{NS}=$ Non-significant at $p \leq 0.05$.

Table 5: Days to flowering of five chile pepper cultivars under the effect of different salinity levels.

\section{Experiment 1}

Days to flowering Days to flowering

\section{Cultivars (C)}

AZ 1904

$111.00 \mathrm{a}$

$111.06 \mathrm{a}$

NuMex Joe Parker

$110.81 \mathrm{a}$

$110.25 a b$

3441

$106.62 \mathrm{~b}$

$107.37 \mathrm{bc}$

NuMex Sandia Select

$110.31 \mathrm{a}$

$110.00 \mathrm{ab}$

LB 25

$105.19 \mathrm{~b}$

$105.44 \mathrm{c}$

LSD (0.05)

3.04

3.27

Salinity $(S ; d S / m)$

0.6 (control)

$113.35 \mathrm{a}$

$112.70 \mathrm{a}$

3

$111.65 \mathrm{a}$

$111.45 \mathrm{a}$

5

$106.25 b$

$105.80 \mathrm{~b}$

8

$103.90 \mathrm{~b}$

$105.35 \mathrm{~b}$

LSD (0.05)

2.72

2.93

Cx S

NS

NS 
$\dagger$ Values within each column followed by same letter(s) are not significantly different according to least significance difference test $(p \leq 0.05)$.

$\mathrm{NS}=$ Non-significant at $p \leq 0.05$.

Table 6: Effect of water salinity levels on photosynthesis $(\mathrm{Pn})$ and stomatal conductance $\left(\mathrm{g}_{\mathrm{s}}\right)$ of five chile-pepper cultivars.

\begin{tabular}{|c|c|c|c|c|}
\hline & \multicolumn{2}{|c|}{ Experiment 1} & \multicolumn{2}{|c|}{ Experiment 2} \\
\hline & 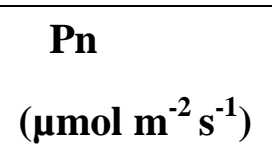 & $\begin{array}{c}\mathrm{gs}_{\mathrm{s}} \\
\left(\mathrm{mmol} \mathrm{m}^{-2} \mathrm{~s}^{-1}\right)\end{array}$ & 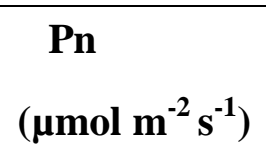 & 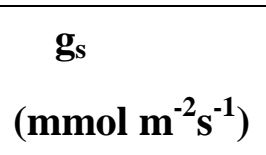 \\
\hline \multicolumn{5}{|l|}{ Cultivars (C) } \\
\hline AZ 1904 & $7.34 \mathrm{~b}$ & $0.096 \mathrm{a}$ & $7.97 \mathrm{ab}$ & $0.098 \mathrm{a}$ \\
\hline NuMex Joe Parker & $6.92 \mathrm{~b}$ & $0.078 \mathrm{~b}$ & $7.11 \mathrm{~b}$ & $0.082 \mathrm{~b}$ \\
\hline 3441 & $8.54 \mathrm{a}$ & $0.099 \mathrm{a}$ & $8.73 \mathrm{a}$ & $0.101 \mathrm{a}$ \\
\hline NuMex Sandia Select & $7.18 \mathrm{~b}$ & $0.083 b$ & $7.12 \mathrm{~b}$ & $0.081 \mathrm{~b}$ \\
\hline LB 25 & $7.65 \mathrm{ab}$ & $0.103 \mathrm{a}$ & $8.44 \mathrm{a}$ & $0.098 \mathrm{a}$ \\
\hline LSD (0.05) & 0.97 & 0.012 & 0.87 & 0.011 \\
\hline \multicolumn{5}{|l|}{ Salinity (S; dS/m) } \\
\hline 0.6 (control) & $8.88 \mathrm{a}$ & $0.144 \mathrm{a}$ & $9.44 \mathrm{a}$ & $0.137 \mathrm{a}$ \\
\hline 3 & $7.92 \mathrm{~b}$ & $0.101 \mathrm{~b}$ & $8.46 \mathrm{~b}$ & $0.107 \mathrm{~b}$ \\
\hline 5 & $6.98 \mathrm{c}$ & $0.070 \mathrm{c}$ & $7.06 \mathrm{c}$ & $0.069 \mathrm{c}$ \\
\hline 8 & $6.33 \mathrm{~d}$ & $0.051 \mathrm{~d}$ & $6.54 \mathrm{c}$ & $0.054 \mathrm{~d}$ \\
\hline LSD (0.05) & 0.86 & 0.011 & 0.78 & 0.010 \\
\hline $\mathbf{C} \times \mathrm{S}$ & NS & NS & NS & NS \\
\hline
\end{tabular}


Table 7: Effect of water salinity levels on relative fresh biomass and relative fruit yield of five chile pepper cultivars.

Experiment 1

Relative fresh Relative fruit shoot weight yield (g)

(g)

\section{Experiment 2}

\section{Relative fresh Relative fruit} shoot weight (g) yield (g)

\section{Cultivars (C)}

$\begin{array}{lllll}\text { AZ } 1904 & 0.750 \mathrm{a} & 0.587 \mathrm{ab} & 0.750 \mathrm{a} & 0.573 \mathrm{a} \\ \text { NuMex Joe Parker } & 0.802 \mathrm{a} & 0.609 \mathrm{ab} & 0.775 \mathrm{a} & 0.596 \mathrm{a} \\ 3441 & 0.751 \mathrm{a} & 0.632 \mathrm{a} & 0.757 \mathrm{a} & 0.615 \mathrm{a} \\ \text { NuMex Sandia Select } & 0.752 \mathrm{a} & 0.577 \mathrm{~b} & 0.743 \mathrm{a} & 0.563 \mathrm{a} \\ \text { LB 25 } & 0.810 \mathrm{a} & 0.604 \mathrm{ab} & 0.784 \mathrm{a} & 0.608 \mathrm{a} \\ \text { LSD }(0.05) & 0.063 & 0.047 & 0.046 & 0.054\end{array}$

Salinity $(S ; d S / m)$

$\begin{array}{lllll}0.6 \text { (control) } & 0.929 \mathrm{a} & 0.891 \mathrm{a} & 0.926 \mathrm{a} & 0.915 \mathrm{a} \\ 3 & 0.828 \mathrm{~b} & 0.762 \mathrm{~b} & 0.811 \mathrm{~b} & 0.783 \mathrm{~b} \\ 5 & 0.681 \mathrm{c} & 0.406 \mathrm{c} & 0.669 \mathrm{c} & 0.355 \mathrm{c} \\ 8 & 0.654 \mathrm{c} & 0.347 \mathrm{~d} & 0.641 \mathrm{c} & 0.311 \mathrm{c} \\ \text { LSD }(0.05) & 0.056 & 0.042 & 0.041 & 0.048 \\ \text { C x S } & \mathrm{NS} & \mathrm{NS} & \mathrm{NS} & \mathrm{NS}\end{array}$

$\dagger$ Values within each column followed by same letter(s) are not significantly different according to least significance difference test $(p \leq 0.05)$.

NS $=$ Non-significant at $p \leq 0.05$. 